Supporting Information

\title{
Investigating Temporal Control in Photoinduced Atom Transfer Radical Polymerization
}

Sajjad Dadashi-Silab, ${ }^{\dagger}, \S$ In-Hwan Lee, ${ }^{\not, \|, \xi}$ Athina Anastasaki, ${ }^{+, *}$ Francesca Lorandi, ${ }^{\dagger}$ Benjaporn Narupai, ${ }^{+}$Neil D. Dolinski, ${ }_{+, \mathcal{S}}$ Michael L. Allegrezza, ${ }^{ \pm}$Marco Fantin, ${ }^{\dagger}$ Dominik Konkolewicz, ${ }^{ \pm}$ Craig J. Hawker, ${ }^{t, \mathcal{S}^{*}}$ and Krzysztof Matyjaszewski $i^{* *}$

${ }^{\dagger}$ Department of Chemistry, Carnegie Mellon University, 4400 Fifth Avenue, Pittsburgh, Pennsylvania 15213, United States

${ }^{\ddagger}$ Materials Research Laboratory, ${ }^{\ddagger}$ Department of Chemistry and Biochemistry, ${ }^{8}$ Materials Department, University of California, Santa Barbara, California, 93106, USA.

${ }^{ \pm}$Department of Chemistry and Biochemistry, Miami University, 651 E High St, Oxford, USA. "Department of Chemistry, Ajou University, Suwon, 16499, Korea

$\S$ S.D.-S. and I.-H.L. contributed equally.

*Email:

km3b@andrew.cmu.edu (K.M.)

hawker@mrl.ucsb.edu (C.J.H.)

athina.anastasaki@mat.ethz.ch (A.A.) 


\section{EXPERIMENTAL}

\section{Materials}

Methyl acrylate (MA; Sigma-Aldrich, 99\%) was passed through a basic alumina column to remove polymerization inhibitor prior to use. Ethyl $\alpha$-bromoisobutyrate (EBiB; Sigma-Aldrich, 98\%), tris(2-pyridylmethyl)amine (TPMA; AmBeed), $N, N, N^{\prime}, N^{\prime \prime}, N^{\prime \prime}$-pentamethyldiethylenetriamine (PMDETA; Sigma-Aldrich, 98\%), triethylamine (TEA), dimethyl sulfoxide (DMSO), $N, N$ dimethylformamide (DMF), and 2,2,6,6-tetramethyl-1-piperidinyloxy (TEMPO; TCI Chemicals, 98\%) were used as received. Tris[2-(dimethylamino)ethyl]amine (Me6TREN) was received from Koei Chemical Co., Ltd. (Japan). Tetraethylammonium tetrafluoroborate (Et4NBF 4 ; Alfa Aesar, 99\%), used as supporting electrolyte for electrochemical measurements, was recrystallized from ethanol and dried in a vacuum oven at $70{ }^{\circ} \mathrm{C}$ for $24 \mathrm{~h}$. A stock solution of $\mathrm{Cu}^{\mathrm{I}}$ was prepared in anhydrous $\mathrm{CH}_{3} \mathrm{CN}$ (Sigma-Aldrich, 98\%) by comproportionation between copper(II) trifluoromethanesulfonate $\left(\mathrm{Cu}^{\mathrm{II}}(\mathrm{OTf})_{2}\right.$; Alfa Aesar, $\left.99 \%\right)$ and a $\mathrm{Cu}$ wire, previously activated by washing in $\mathrm{MeOH} / \mathrm{HCl}(3 / 1 \mathrm{vol})$ and rinsed with water and acetone. The exact concentration of $\mathrm{Cu}^{\mathrm{I}}(\mathrm{OTf})$ was determined by spectrophotometric titration, using 2,9-dimethyl-1,10-phenanthroline as a specific ligand $\left(\varepsilon=8458 \mathrm{M}^{-1} \mathrm{~cm}^{-1}\right)$ in a 3-fold excess with respect to the metal.

\section{Instrumentation}

${ }^{1} \mathrm{H}$ nuclear magnetic resonance ( ${ }^{1} \mathrm{H}$ NMR) measurements were performed on a Bruker Avance ${ }^{\mathrm{TM}}$ III $500 \mathrm{MHz}$ spectrometer. Molecular weight properties of the polymers were determined by sizeexclusion chromatography (SEC). The SEC instrument used a Waters 515 pump and a Waters 2414 differential refractometer using PSS columns (SDV $10^{5}, 10^{3}$, and $500 \AA$ ) with THF as eluent at $35^{\circ} \mathrm{C}$ and a flow rate of $1 \mathrm{~mL} \mathrm{~min}{ }^{-1}$. Linear poly(methyl methacrylate) standards were used for calibration.

The electrochemical measurements of ATRP parameters were conducted in a 6-neck electrochemical cell, connected to an Autolab PGSTAT100N potentiostat/galvanostat, run by a PC with NOVA 2.1 software (Metrohm USA). The cell was equipped with a three-electrode system. The counter electrode was a Platinum foil, the reference electrode was an home-made an $\mathrm{Ag}|\mathrm{AgI}|(0.1 \mathrm{M} n$-Bu4NI in DMF), whereas the working electrode was a glassy carbon tip (Metrohm, $3 \mathrm{~mm}$ dia.). The latter was cleaned before each experiment with a $0.25 \mathrm{~mm}$ diamond 
paste and ultrasonically rinsed with ethanol for $5 \mathrm{~min}$. The ferrocenium/ferrocene redox couple was used as internal standard to convert all potentials to the aqueous saturated calomel electrode (SCE).

\section{General procedure for temporal control in photoinduced ATRP of MA via in situ NMR monitoring}

To a 1-dram glass vial equipped with stir bar, $\mathrm{CuBr}_{2}(1 \mathrm{mg}, 0.0044 \mathrm{mmol}, 0.02$ equiv.), $\mathrm{Me} 6 \mathrm{TREN}$ ( $7 \mu \mathrm{L}, 0.027 \mathrm{mmol}, 0.12$ equiv.) and DMSO-d $6(2 \mathrm{ml})$ were added sequentially. MA was placed in another 1-dram glass vial. The vials were then degassed by purging with argon for 10 minutes. Under argon atmosphere, MA ( $1 \mathrm{~mL}, 11.1 \mathrm{mmol}, 50$ equiv.) was taken and added to the vial containing other reagents. Lastly, $\mathrm{EBiB}$ ( $33 \mu \mathrm{L}, 0.22 \mathrm{mmol}, 1$ equiv.) was added to the vial, using a stock solution. The $0.35-0.40 \mathrm{~mL}$ of reaction mixture was then transferred to an NMR tube under argon atmosphere in the dark. The optical fiber and teflon insert were placed into the NMR tube such that the fiber was ca. $2 \mathrm{~mm}$ above the solution. All NMR measurements were performed as an array and a LabVIEW program connected to a T-cube LED driver was used to automate 'on'/'off' times of a $405 \mathrm{~nm}$ LED.

\section{General procedure for temporal control in photoinduced ATRP of MA under batch conditions}

A $20-\mathrm{mL}$ vial equipped with a stir bar was sealed with a rubber septum, and subjected to vacuum and backfilled with nitrogen for 5 times. DMSO and MA were degassed with nitrogen in separate vials for at least $45 \mathrm{~min}$. DMSO ( $5 \mathrm{~mL}$ ), MA ( $5 \mathrm{~mL}, 55.5 \mathrm{mmol}, 200$ equiv.), $\mathrm{CuBr}_{2}$ (1.24 mg, $5.55 \mu \mathrm{mol}, 0.02$ equiv.), Me6TREN ( $9 \mu \mathrm{L}, 33.3 \mu \mathrm{mol}, 0.12$ equiv.), and $\mathrm{EBiB}$ ( $40 \mu \mathrm{L}, 0.27 \mathrm{mmol}$, 1 equiv.) were added into the vial under nitrogen. The vial was degassed with nitrogen for $2 \mathrm{~min}$ more and was irradiated under violet LEDs to start the polymerization. Samples were taken periodically for ${ }^{1} \mathrm{H}$ NMR and SEC analyses.

General procedure for determination of $K_{\mathrm{ATRP}}$ and $\boldsymbol{k}_{\text {act }}$ by rotating disk electrode:

The three electrodes and a magnetic stirring bar were put in the electrochemical cell. Et $4 \mathrm{NBF}_{4}$ supporting electrolyte $(0.326 \mathrm{~g}, 0.1 \mathrm{M})$ and $15 \mathrm{~mL}$ of DMSO/MA $1 / 1$ mixture were inserted into 
the cell. Then, the desired amount of ligand was added. TEMPO was also added in the experiments for determining the rate constant of ATRP activation, $k_{\text {act. }}$ After degassing the solution for ca. 15 min, cyclic voltammetry (CV) was run to check for impurities and verify the absence of oxygen. The RDE rotation was set at $2500 \mathrm{rpm}$ for the determination of the equilibrium constant $K_{\mathrm{ATRP}}$, or $4000 \mathrm{rpm}$ for measuring $k_{\text {act. }}$ A constant potential, $E_{\text {app }}$, was applied, and the resulting current was recorded. $E_{\text {app }}$ values were selected such as to follow the oxidation of $\mathrm{L} / \mathrm{Cu}^{\mathrm{I}}$ under mass transfer control in a potential range where no other process occurred. The required amount of $\mathrm{Cu}^{\mathrm{I}}$ was withdrawn with a syringe from the stock solution, under inert atmosphere, and injected into the cell. The initiator was injected into the cell a few seconds after injecting $\mathrm{Cu}^{\mathrm{I}}$. After the measurements, a $\mathrm{CV}$ was recorded to verify the presence of $\mathrm{L} / \mathrm{Br}-\mathrm{Cu}{ }^{\mathrm{II}}$ complexes and determining their reduction potentials. A 50-fold excess of initiator relative to $\mathrm{Cu}^{\mathrm{I}}$ was typically used for

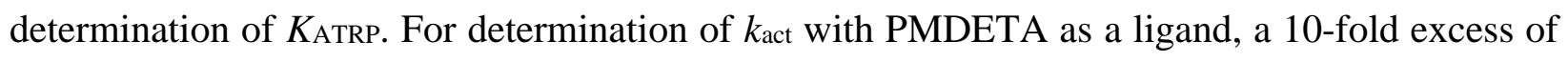
initiator was used due to the lower activity of the catalyst. Moreover, when PMDETA was used as a ligand, the initiator was injected before $\mathrm{Cu}^{\mathrm{I}}$ to avoid any issues due to the complexation of $\mathrm{L} / \mathrm{Cu}^{\mathrm{I}}$ by MA. ${ }^{1}$ The values of $K$ ATRP and $k_{\text {act }}$ were obtained from the decay of the current with time, according to previous reports. ${ }^{2,3}$ 


\section{Polymerization results:}
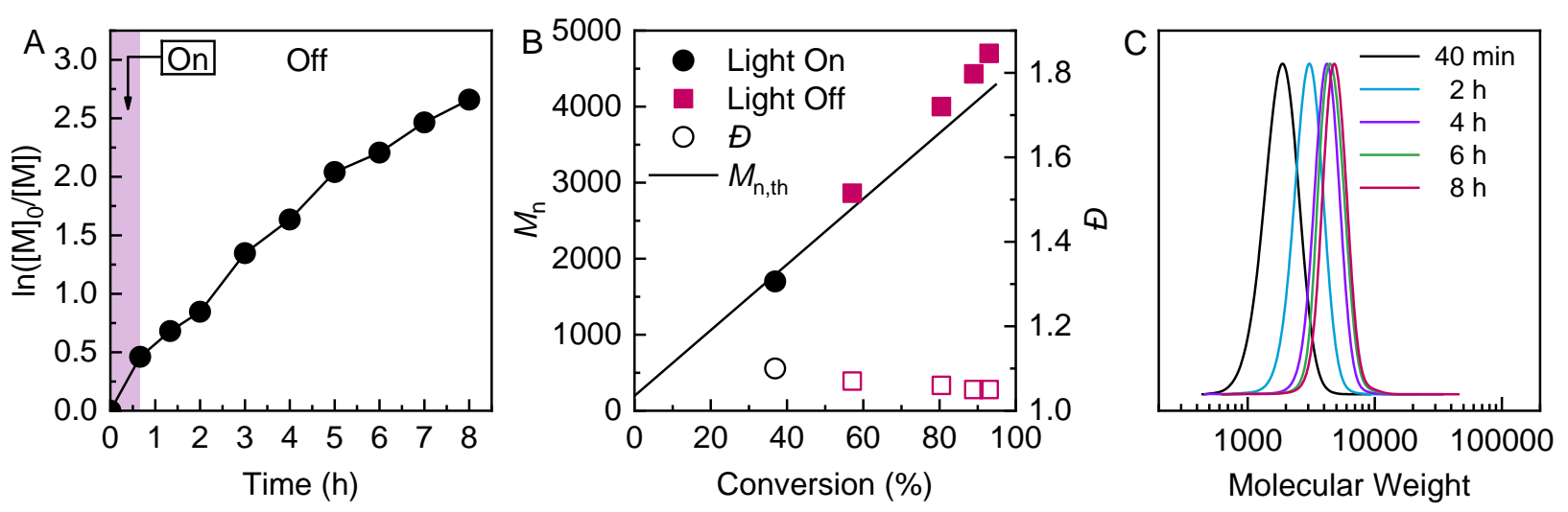

Figure S1. Temporal control in photoATRP of MA under violet LEDs. Reaction conditions: $[\mathrm{MA}] /[\mathrm{EBiB}] /\left[\mathrm{CuBr}_{2}\right] /\left[\mathrm{Me}_{6} \mathrm{TREN}\right]=50 / 1 / 0.02 / 0.12$ in $50 \mathrm{vol} \%$ DMSO $([\mathrm{MA}]=5.5$ M), irradiated under violet LEDs $\left(\lambda_{\max }=394 \mathrm{~nm}, 2.6 \mathrm{~mW} / \mathrm{cm}^{2}\right)$ for $40 \mathrm{~min}$. (A) Kinetics of the polymerization, (B) number-average molecular weight $\left(M_{\mathrm{n}}\right.$, solid points) and dispersity ( $D$, open points) as a function of monomer conversion. (C) SEC traces. Obtained under batch conditions. 

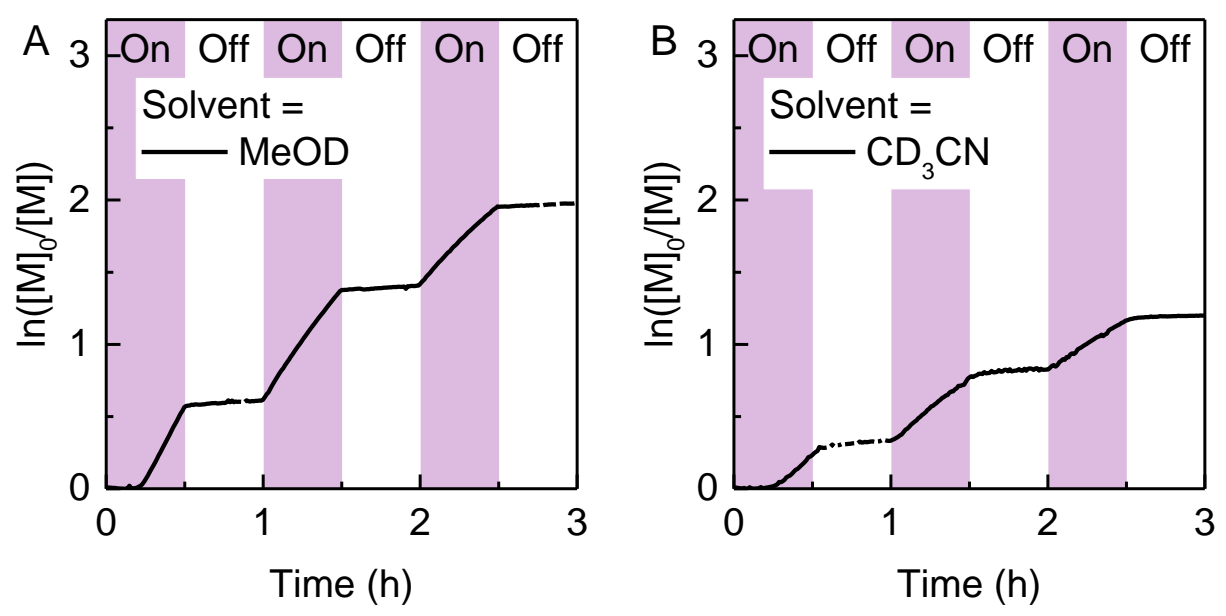

\begin{tabular}{ccccc}
\hline & & & & $k_{\text {off }} / k_{\text {on }}$ \\
\cline { 5 - 5 } Solvent & Conversion $(\%)$ & $M_{\mathrm{n}}$ & $Ð$ & $1^{\text {st }}\left|2^{\text {nd }}\right| 3^{\text {rd }}$ \\
\hline MeOD & 86 & 4200 & 1.09 & $0.04|0.04| 0.05$ \\
$\mathrm{CD}_{3} \mathrm{CN}$ & 70 & 3300 & 1.11 & $0.11|0.08| 0.05$
\end{tabular}

Figure S2. Temporal control achieved in (a) $\mathrm{MeOD}$ and (b) $\mathrm{CD}_{3} \mathrm{CN}$. Reaction conditions: $[\mathrm{MA}] /[\mathrm{EBiB}] /\left[\mathrm{CuBr}_{2}\right] /\left[\mathrm{Me}_{6} \mathrm{TREN}\right]=50 / 1 / 0.01 / 0.06$. Obtained via in situ NMR monitoring.
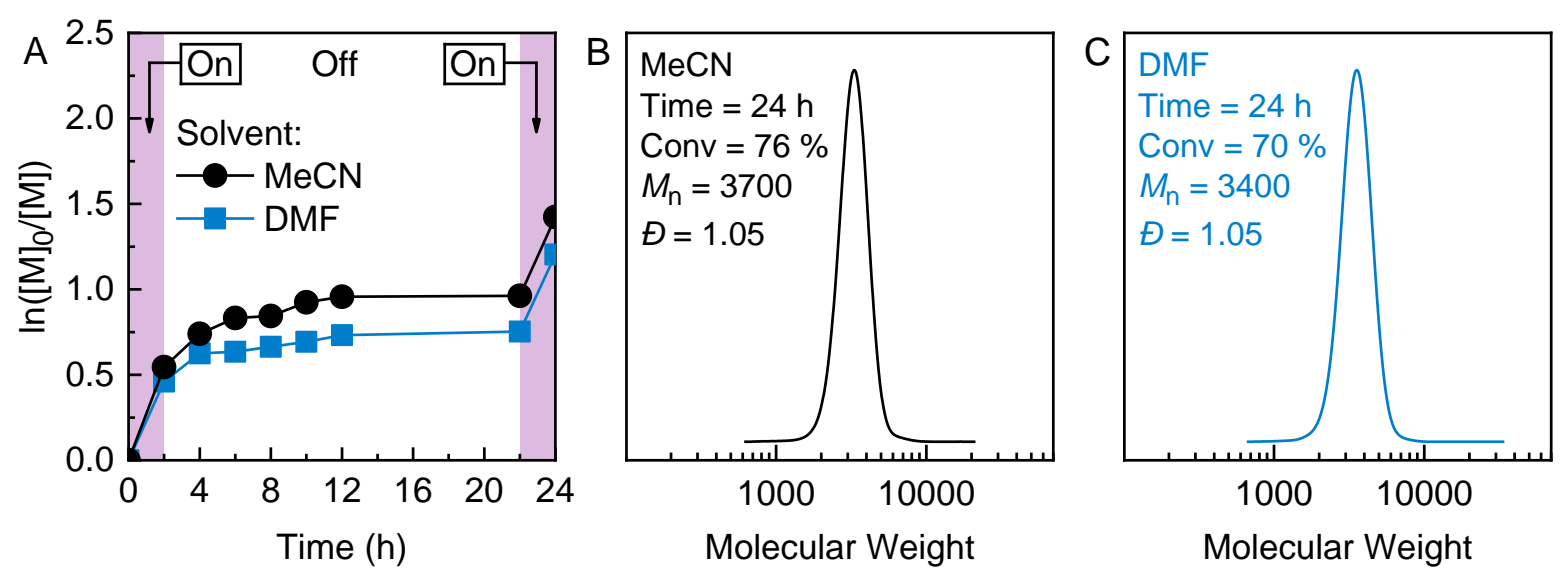

Figure S3. Results of temporal control experiments performed in MeCN of DMF. Reaction conditions: $[\mathrm{MA}] /[\mathrm{EBiB}] /\left[\mathrm{CuBr}_{2}\right] /\left[\mathrm{Me}_{6} \mathrm{TREN}\right]=50 / 1 / 0.02 / 0.12$ in $50 \mathrm{vol} \%$ solvent $(\mathrm{MeCN}$ or DMF, $[\mathrm{MA}]=5.5 \mathrm{M})$, irradiated under violet LEDs $\left(\lambda_{\max }=394 \mathrm{~nm}, 2.6\right.$ $\mathrm{mW} / \mathrm{cm}^{2}$ ). Obtained under batch conditions. 

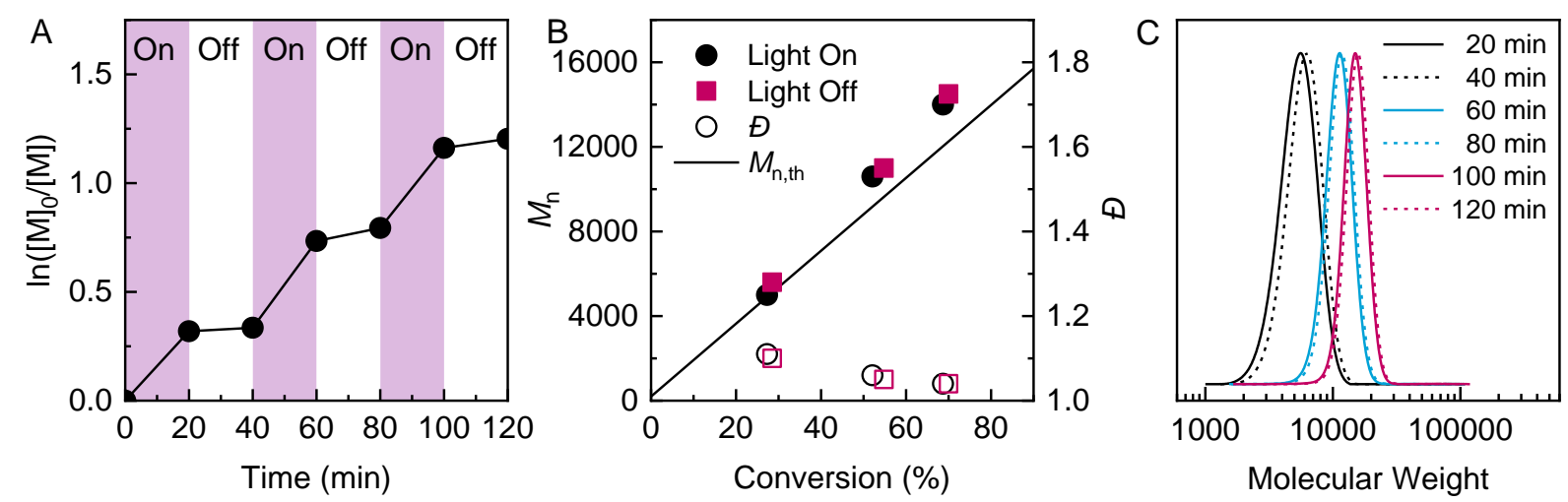

Figure S4. Temporal control in photoATRP of MA under violet LEDs. Reaction conditions: $[\mathrm{MA}] /[\mathrm{EBiB}] /\left[\mathrm{CuBr}_{2}\right] /\left[\mathrm{Me}_{6} \mathrm{TREN}\right]=200 / 1 / 0.02 / 0.12$ in $50 \mathrm{vol} \%$ DMSO $([\mathrm{MA}]=5.5$ $\mathrm{M})$, irradiated under violet LEDs $\left(\lambda_{\max }=394 \mathrm{~nm}, 2.6 \mathrm{~mW} / \mathrm{cm}^{2}\right)$. (A) Kinetics of the polymerization, (B) number-average molecular weight $\left(M_{\mathrm{n}}\right.$, solid points $)$ and dispersity ( $\oslash$, open points) as a function of monomer conversion. (C) SEC traces; solid lines correspond for light on and dashed lines correspond for light off periods. Obtained under batch conditions.
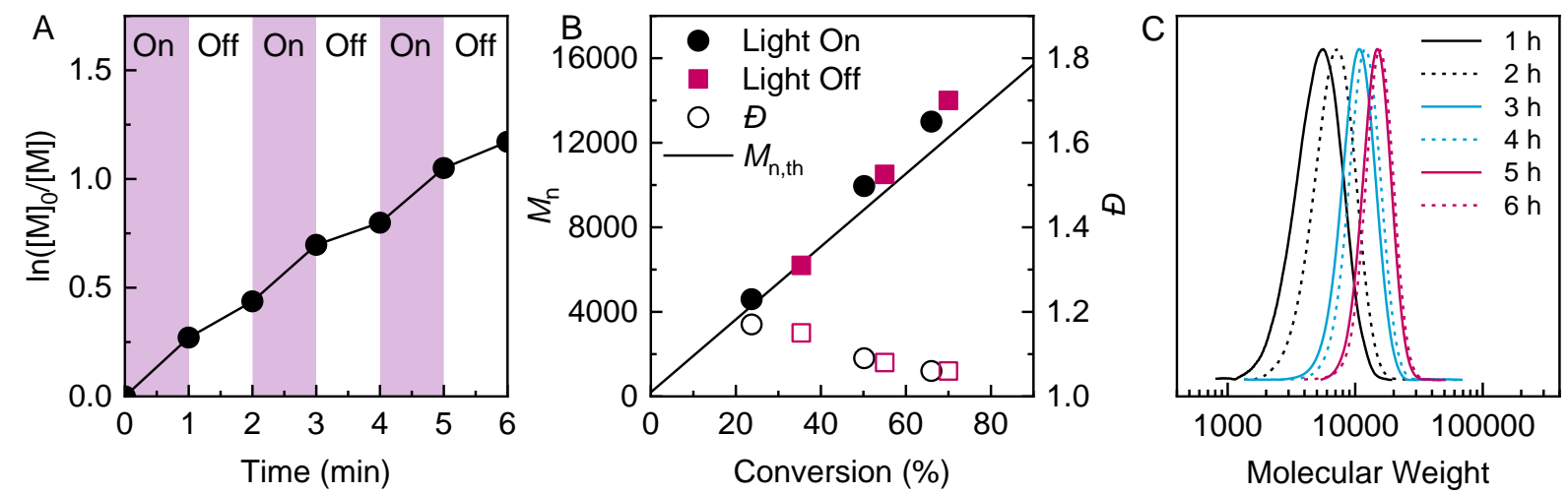

Figure S5. Temporal control in photoATRP of MA using TPMA. Reaction conditions: $[\mathrm{MA}] /[\mathrm{EBiB}] /\left[\mathrm{CuBr}_{2}\right] /[\mathrm{TPMA}] /[\mathrm{TEA}]=200 / 1 / 0.02 / 0.02 / 0.4$ in $50 \mathrm{vol} \% \mathrm{DMSO}$ $([\mathrm{MA}]=5.5 \mathrm{M})$, irradiated under violet LEDs $\left(\lambda_{\max }=394 \mathrm{~nm}, 2.6 \mathrm{~mW} / \mathrm{cm}^{2}\right) .(\mathrm{A})$ Kinetics of the polymerization, (B) number-average molecular weight $\left(M_{\mathrm{n}}\right.$, solid points) and dispersity ( $Ð$, open points) as a function of monomer conversion. (C) SEC traces; solid lines correspond for light on and dashed lines correspond for light off periods. Obtained under batch conditions. 

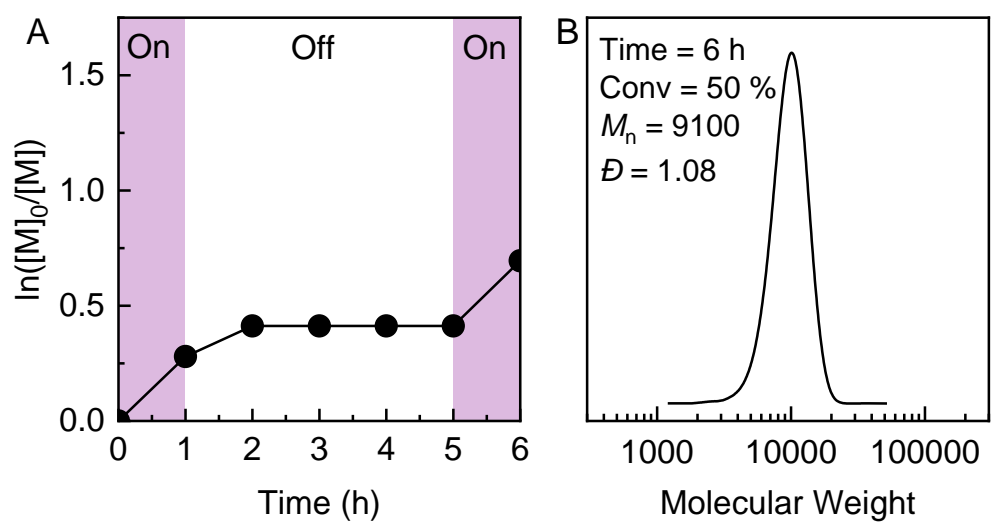

Figure S6. Temporal control in photoATRP of MA using TPMA. Reaction conditions: $[\mathrm{MA}] /[\mathrm{EBiB}] /\left[\mathrm{CuBr}_{2}\right] /[\mathrm{TPMA}] /[\mathrm{TEA}]=200 / 1 / 0.02 / 0.02 / 0.4$ in 50 vol\% DMSO $([\mathrm{MA}]=5.5 \mathrm{M})$, irradiated under violet LEDs $\left(\lambda_{\max }=394 \mathrm{~nm}, 2.6 \mathrm{~mW} / \mathrm{cm}^{2}\right) .(\mathrm{A})$ Kinetics of the polymerization and (B) SEC traces. Obtained under batch conditions.
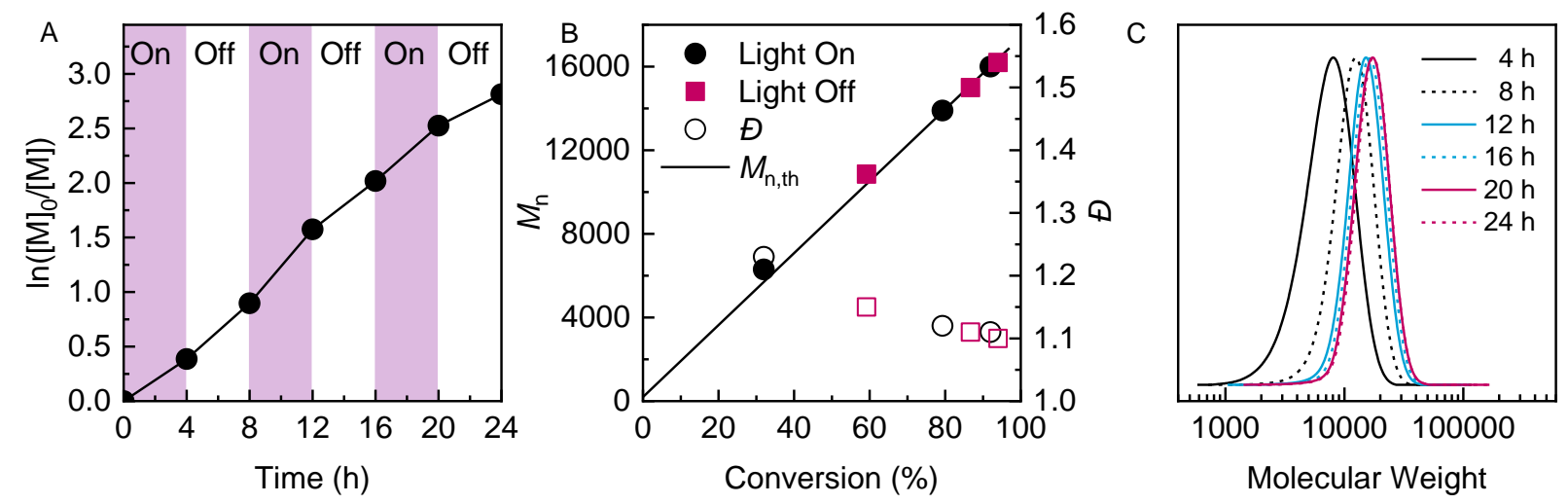

Figure S7. Temporal control in photoATRP of MA using PMDETA. Reaction conditions: $[\mathrm{MA}] /[\mathrm{EBiB}] /\left[\mathrm{CuBr}_{2}\right] /[\mathrm{PMDETA}]=200 / 1 / 0.02 / 0.12$ in $50 \mathrm{vol} \%$ DMSO $([\mathrm{MA}]=5.5$ M), irradiated under violet LEDs $\left(\lambda_{\max }=394 \mathrm{~nm}, 2.6 \mathrm{~mW} / \mathrm{cm}^{2}\right)$. (A) Kinetics of the polymerization, (B) number-average molecular weight ( $M_{\mathrm{n}}$, solid points) and dispersity ( $\oslash$, open points) as a function of monomer conversion. (C) SEC traces; solid lines correspond for light on and dashed lines correspond for light off periods. Obtained under batch conditions. 

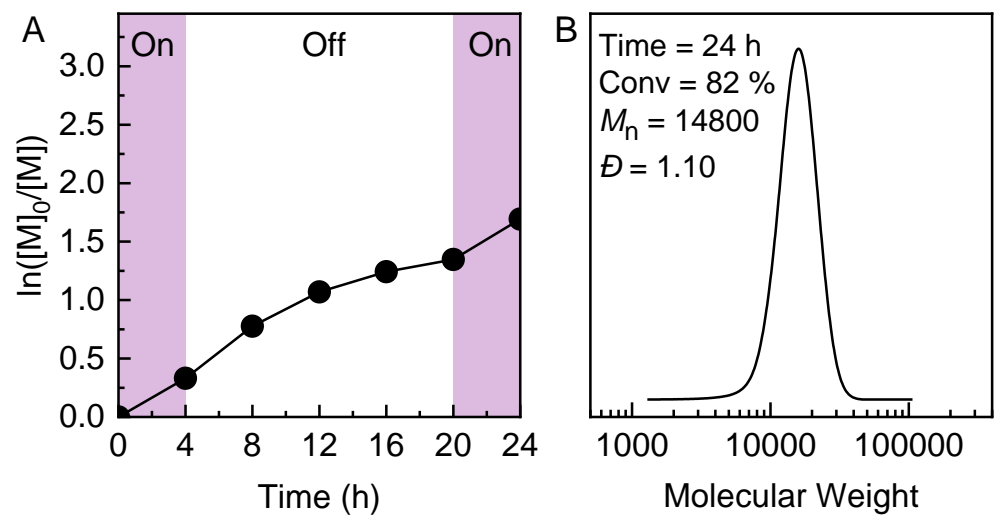

Figure S8. Temporal control in photoATRP of MA using PMDETA. Reaction conditions: $[\mathrm{MA}] /[\mathrm{EBiB}] /\left[\mathrm{CuBr}_{2}\right] /[\mathrm{PMDETA}]=200 / 1 / 0.02 / 0.12$ in 50 vol\% DMSO, irradiated under violet LEDs $\left(\lambda_{\max }=394 \mathrm{~nm}, 2.6 \mathrm{~mW} / \mathrm{cm}^{2}\right)$. (A) Kinetics of the polymerization and (B) SEC traces. Obtained under batch conditions. 


\section{PREDICI simulations:}

Simulations using PREDICI software were conducted to simulate how polymerization would behave in temporal control experiments upon removal of light. The model is presented in Scheme S1, and the rate constant values for the reactions below were adopted from literature reports ${ }^{4-6}$ or measured in this work.

\begin{tabular}{|c|c|c|c|c|}
\hline & Reactions & & Rate constants & Reference \\
\hline Activation: & $P_{n}-B r+L / C u^{\prime}$ & $\stackrel{k_{\text {act }}}{\longrightarrow} \mathrm{P}_{\mathrm{n}}^{\cdot}+\mathrm{L} / \mathrm{Br}-\mathrm{Cu}$ & $k_{\mathrm{act}}=60 \mathrm{M}^{-1} \mathrm{~s}^{-1}$ & This work \\
\hline Deactivation: & $\mathrm{P}_{\mathrm{n}}^{\cdot}+\mathrm{L} / \mathrm{Br}-\mathrm{Cu} \mathrm{u}^{\prime \prime}$ & $\stackrel{k_{\text {deact }}}{\longrightarrow} \mathrm{P}_{\mathrm{n}}-\mathrm{Br}+\mathrm{L} / \mathrm{Cu}^{\prime}$ & $k_{\text {deact }}=3.8 \times 10^{7} \mathrm{M}^{-1} \mathrm{~s}^{-1}$ & This work \\
\hline Propagation: & $P_{n}+M$ & $\stackrel{k_{\mathrm{p}}}{\longrightarrow} \mathrm{P}_{\mathrm{n}+1}^{\cdot}$ & $k_{\mathrm{p}}=1.5 \times 10^{4} \mathrm{M}^{-1} \mathrm{~s}^{-1}$ & Ref. 4 \\
\hline OMRP eq.: & $P_{n}^{\cdot}+L / C u^{\prime}$ & $\frac{k_{\text {ass }}}{k_{\text {diss }}} P_{n^{-}}-\mathrm{L} / \mathrm{Cu}^{\prime \prime}$ & $\begin{array}{l}k_{\text {ass }}=5.8 \times 10^{8} \mathrm{M}^{-1} \mathrm{~s}^{-1} \\
k_{\text {diss }}=6.4 \times 10^{2} \mathrm{~s}^{-1}\end{array}$ & Ref. 5 \\
\hline CRT: & $P_{m} \cdot+P_{n}-L / C u^{\prime \prime}$ & $\stackrel{k_{\mathrm{CRT}}}{\longrightarrow} \mathrm{P}_{\text {dead }}+\mathrm{L} / \mathrm{Cu}$ & $k_{\mathrm{CRT}}=1.0 \times 10^{8} \mathrm{M}^{-1} \mathrm{~s}^{-1}$ & This work \\
\hline Radical term: & $P_{n}+P_{m} \cdot$ & $\stackrel{k_{\mathrm{t}}}{\longrightarrow} \mathrm{P}_{\mathrm{n}}-\mathrm{P}_{\mathrm{m}}$ & $k_{\mathrm{t}}=2.4 \times 10^{8} \mathrm{M}^{-1} \mathrm{~s}^{-1}$ & Ref. 6 \\
\hline
\end{tabular}

Scheme S1. PREDICI model for simulating ATRP in the dark in the presence of TPMA ligand. The values of $k_{\text {act }}$ and $k_{\text {deact }}$ were measured by electrochemistry as explained above, $k$ CRT value was estimated to fit the experimental data. 

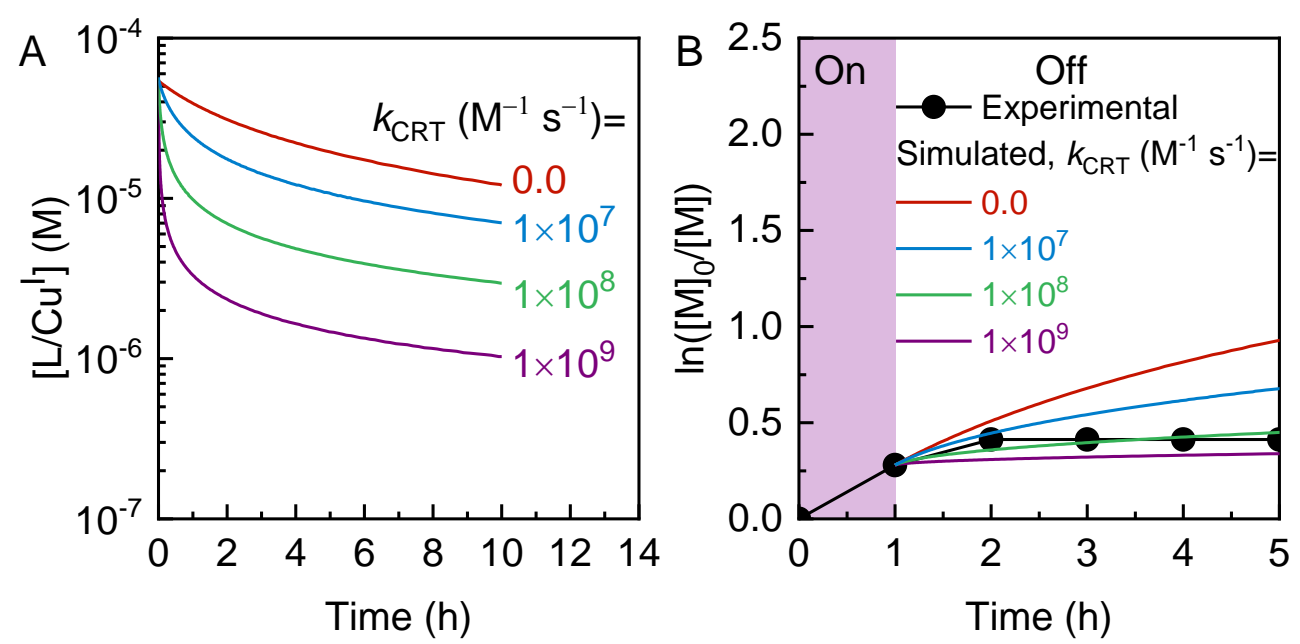

Figure S9. Results of PREDICI simulations. (A) Evolution of $\left[\mathrm{L} / \mathrm{Cu} \mathrm{u}^{\mathrm{I}}\right]$ where $\mathrm{L}=\mathrm{TPMA}$ in the dark (no activator regeneration) as simulated by PREDICI considering only bimolecular radical termination (shown in red) or bimolecular radical termination and CRT (shown in blue, green, or purple). (B) Overlay of experimental (shown in black) and simulated kinetics results in the dark periods considering only bimolecular radical termination (shown in red) or bimolecular radical termination and CRT (shown in blue, green, or purple). Initial reaction conditions: $[\mathrm{MA}] /[\mathrm{EBiB}] /\left[\mathrm{CuBr}_{2}\right] /[\mathrm{TPMA}]=$ 200/1/0.02/0.12 in 50 vol\% DMSO.

\section{References}

(1) Braunecker, W. A.; Tsarevsky, N. V.; Pintauer, T.; Gil, R. R.; Matyjaszewski, K. Quantifying Vinyl Monomer Coordination to $\mathrm{CuI}$ in Solution and the Effect of Coordination on Monomer Reactivity in Radical Copolymerization, Macromolecules 2005, 38, 4081.

(2) Isse, A. A.; Bortolamei, N.; De Paoli, P.; Gennaro, A. On the mechanism of activation of copper-catalyzed atom transfer radical polymerization, Electrochim. Acta 2013, 110, 655.

(3) Lorandi, F.; Fantin, M.; Isse, A. A.; Gennaro, A.; Matyjaszewski, K. New protocol to determine the equilibrium constant of atom transfer radical polymerization, Electrochim. Acta 2018, 260, 648.

(4) Buback, M.; Kurz, C. H.; Schmaltz, C. Pressure dependence of propagation rate coefficients in free-radical homopolymerizations of methyl acrylate and dodecyl acrylate, Macromol. Chem. Phys. 1998, 199, 1721.

(5) Fantin, M.; Lorandi, F.; Ribelli, T. G.; Szczepaniak, G.; Enciso, A. E.; Fliedel, C.; Thevenin, L.; Isse, A. A.; Poli, R.; Matyjaszewski, K. Impact of Organometallic Intermediates on Copper-Catalyzed Atom Transfer Radical Polymerization, Macromolecules 2019, 52, 4079.

(6) Buback, M.; Kuelpmann, A.; Kurz, C. Termination Kinetics of Methyl Acrylate and Dodecyl Acrylate Free-Radical Homopolymerizations up to High Pressure, Macromol. Chem. Phys. 2002, 203, 1065. 